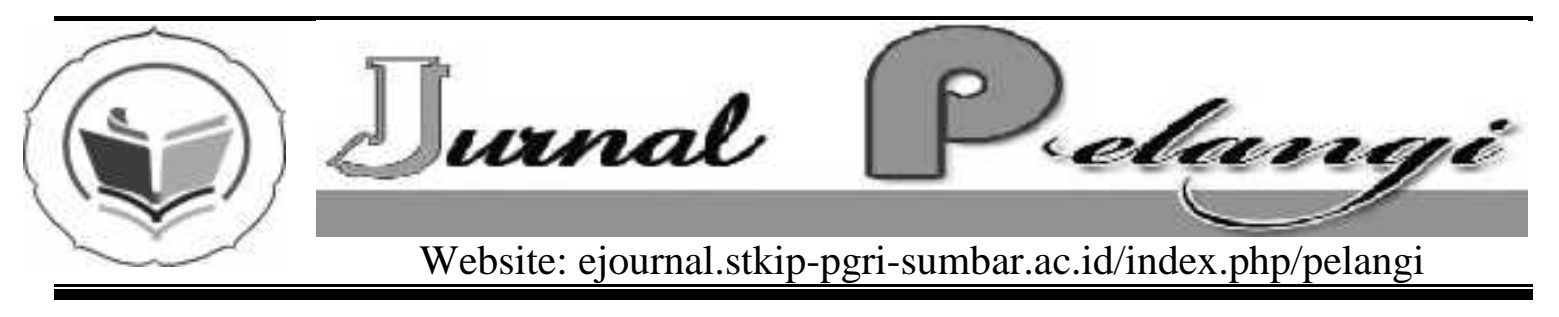

\title{
MENCIPTAKAN PEMBELAJARAN MATEMATIKA YANG KREATIF DAN MENYENANGKAN
}

\author{
Rahmi \\ STKIP PGRI Sumatera Barat \\ rahmi_65@yahoo.com
}

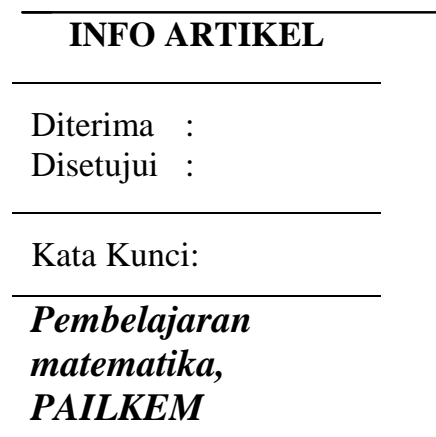

\begin{abstract}
Abstrak
Tujuan umum dari pengalaman mata pelajaran matematika pada siswa sekolah dasar dan menengah adalah; pertama mempersiapkan siswa untuk menghadapi perubahan kehidupan nyata melalui latihan pemikiran berdasarkan efektivitas, effisiensi, kejujuran, kritikus, rasional, dan cara yang logis dalam berpikir. Kedua, mempersiapkan siswa untuk menerapkan prinsip mental matematika dalam kehidupan sehari-hari mereka sebagai dasar dalam belajar untuk disiplin lain. Mengenai pentingnya belajar dari hal ini, guru matematika harus mampu menciptakan proses belajar mengajar yang efektif untuk merangsang dan membangkitkan semangat siswa dalam belajar matematika. Salah satu strategi yang dapat meningkatkan siswa dalam belajar matematika adalah PAILKEM (Pembelajaran Aktif, Inovatif, Lingkungan, Kreatif, Efektif, Dan Menarik). Ada dialog interaktif antara guru dan siswa dan siswa untuk siswa selama proses. Proses belajar-mengajar ini menciptakan situasi kondusif di mana siswa merasa bebas untuk mendiskusikan masalah mereka dalam belajar matematika untuk guru dan teman sekelas mereka. Pada akhirnya, melalui strategi ini, siswa dapat meningkatkan kemampuan mereka dalam belajar dan diharapkan proses belajar mengajar akan dilakukan dalam hasil yang optimal.
\end{abstract}

\begin{tabular}{l} 
Abstract \\
\hline The general puposes of experiencing math subject to \\
elementary and middle school students are; first preparing the \\
students to face the changing of real life through the thinking \\
rehearsal based on the effective, effisien, honesty, critical, \\
rationale, and logical way of thinking, and second, preparing \\
the students to apply the mental principle of math in their daily \\
life and as basic in learning other disciplines. Regarding to the \\
importance of learning this subject, teacher of math should be \\
able to create an effective teaching learning process to \\
stimulate and to rise students enthusiasm in learning match.
\end{tabular}


One of the strategy that can increase students desire in learning math is PAILKEM (Pembelajaran Aktif, Inovatif, Lingkungan, Kreatif, Efektif, dan Menarik). There is an interactive dialoque between teacher students and studentsstudents, during teaching-learning process.This creates a condusive situation in wich students feel free to discuss their problems in learning math to their teachers and their classmates. At the end, through this strategy, students can increase their ability in learning and it is hoped that teaching learning process will be done in optimal achievement.

\section{PENDAHULUAN}

Perkembangan ilmu pengetahuan dan teknologi memungkinkan semua informasi dengan cepat dan mudah diperoleh dari berbagai sumber dan tempat di dunia. Untuk itu siswa perlu memiliki kemampuan memperoleh, memilih dan mengelola informasi supaya bertahan pada keadaan yang selalu berubah. Kemampuan ini membutuhkan pemikiran kritis, sistematis, logis, kreatif dan kemampuan bekerjasama. Cara berfikir tersebut dapat dikembangkan melalui belajar matematika, karena matematika mempunyai struktur dan keterkaitan yang kuat dan jelas antara konsepnya sehingga memungkinkan siswa terampil berfikir rasional. Sebagaimana yang diungkapkan Erman (2003) bahwa: tujuan umum diberikannya pelajaran matematika pada jenjang pendidikan dasar dan menengah meliputi dua hal yaitu:

1) Mempersiapkan siswa agar sanggup menghadapi perubahan keadaan di dalam kehidupan dan dunia yang selalu berkembang, melalui latihan bertindak atas dasar pemikiran yang logis, rasional, kritis, jujur, efektif, dan efisien.

2) Mempersiapkan siswa agar dapat menggunakan matematika dan pola pikir matematika dalam kehidupan sehari-hari, dan dalam mempelajari berbagai ilmu pendidikan.

Mengingat pentingnya peranan matematika, menimbulkan tugas bagi guru khususnya guru matematika sebagai orang yang terlibat langsung dalam pembelajaran. Agar melaksanakan pembelajaran yang tepat sehingga dapat membangkitkan antusiasme siswa dan mendorong siswa mengkonstruksi pengetahuannya sendiri. Tentunya hal ini terwujud apabila guru selalu menyiapkan segala sesuatu yang berhubungan dengan program pembelajaran yang akan berlangsung.

Kenyataan yang ditemui saat ini pembelajaran matematika tetap merupakan masalah yang banyak dibicarakan oleh para pakar pendidikan dan orangtua. Permasalahan-permasalahan pendidikan matematika yang muncul hingga kini antara lain: kesenjangan antara konsep kurikulum dengan pelaksanaan, kurangnya motivasi dan minat belajar matematika siswa. Kondisi tersebut mengakibatkan hasil belajar matematika yang diperoleh siswa relatif rendah.

Berpangkal tolak pada uraian diatas maka penulis mencoba mengakaji dalam tuliasan ini untuk menjawab pertanyaan bagaimana cara menciptakan pembelajaran matematika yang kreatif dan menyenangkan. Dengan harapan hasil belajar matematika siswa menjadi lebih baik.

\section{METODE PENELITIAN}

Strategi Pembelajaran PAILKEM merupakan salah satu strategi yang dapat diterapkan dalam 
kegiatan pembelajaran matematika. Ungkapan ini didasarkan pada pendapat Uno (2011) yang mengatakan bahwa strategi PAILKEM tertuju pada bagaimana cara: 1) mengorganisasikan materi pembelajaran, 2) menyampaikan atau menggunakan metode pembelajaran, dan 3) mengelola pembelajaran sebagaimana yang dikehendaki oleh ilmuan pembelajaran saat ini Jadi dapat disimpulkan bahwa dengan pengorganisasian yang baik, penggunaan metode pembelajaran yang tepat dan mengelola pelaksanaan pembelajaran dengan baik akan tercipta pembelajaran matematika yang kreatif dan menyenangkan terhadap data yang telah direduksi baik data perencanaan, pelaksanaan, maupun data evaluasi. Analisis data dilakukan dengan cara terpisah-pisahagar ditemukan berbagai informasi yang spesifik dan terfokus pada masalah penelitian. Data tersebut direduksi berdasarkan masalah yang diteliti, diikuti penyajian data dan terakhir penarikan kesimpulan.

\section{HASIL DAN PEMBAHASAN}

Berbagai pendapat tentang pengertian matematika menurut Suherman (2003) adalah matematika merupakan bahasa simbol; matematika adalah bahasa numeric; matematika adalah bahasa yang dapat menghilangkan sifat kabur, majemuk dan emosional; matematika adalah metode berpikir logis; matematika adalah sarana berpikir; matematika adalah sains mengenai kuantitas dan besaran; matematika adalah suatu sains yang bekerja menarik kesimpulan-kesimpulan yang perlu; matematika adalah sains formal yang murni; matematika adalah sain yang memanipulasi symbol; matematika adalah ilmu tentang bilangan dan ruang; matematika adalah ilmu yang mempelajari tentang hubungan pola, bentuk dan struktur; matematika adalah ilmu yang abstrak dan deduktif dan matematika adalah aktivitas manusia.

Kemudian Johnson dan Rising (dalam Ruseffendi 1992) mengatakan bahwa matematika adalah pola berpikir, pola mengorganisasikan pembuktian yang logik; matematika itu adalah bahasa yang menggunakan istilah yang didefenisikan dengan cermat, jelas dan akurat, representasinya dengan simbol dan padat, lebih berupa bahasa simbol mengenai ide (gagasan) daripada mengenai bunyi; matematika adalah pengetahuan struktur yang terorganisasikan sifat-sifat atau teoriteori itu dibuat secara deduktif berdasarkan kepada unsur-unsur yang didefenisikan atau tidak didefenisikan, aksioma-aksioma, sifat-sifat atau teori-teori yang telah dibuktikan kebenarannya; matematika adalah ilmu tentang pola, keteraturan pola atau ide; dan matematika itu adalah seni, keindahannya terdapat pada keteraturan dan keharmonisannya. Jadi menurut Johnson Rising, jelas bahwa matematika adalah ilmu deduktif.

Berpedoman pada kutipan di atas dapat diketahui bahwa, baik isi maupun metode mencari kebenaran dalam matematika berbeda dengan ilmu pengetahuan umum lainnya. Metode mencari kebenaran yang dipakai oleh matematika adalah metode deduktif, sedangkan pada ilmu pengetahuan alam adalah metode induktif atau eksperimen. Sementara dalam matematika mencari kebenaran itu bisa dimulai dengan cara induktif, yang kemudian generalisasi yang benar untuk semua keadaan tadi harus bisa dibuktikan secara deduktif. Dalam matematika, suatu generalisasi, sifat, teori atau dalil itu belum dapat diterima kebenarannya sebelum dapat dibuktikan secara deduktif. Jadi dalam matematika 
siswa dilatih untuk berfikir sistematis sesuai struktur dan keterkaitan yang kuat serta jelas antara konsep sehingga memungkinkan siswa terampil berfikir rasional.

Selain pandangan di atas ada juga pendapat terkenal yang memandang matematika sebagai pelayan dan sekaligus raja dari ilmu-ilmu lain. Sebagai pelayan, matematika adalah ilmu dasar yang mendasari dan melayani berbagai ilmu pengetahuan lain. Sebagai raja, perkembangan matematika tak tergantung pada ilmu-ilmu lain.

Pembelajaran merupakan suatu upaya menciptakan kondisi yang memungkinkan siswa dapat belajar. Secara eksplisit terlihat bahwa dalam pembelajaran ada kegiatan memilih, menetapkan, dan mengembangkan metode untuk mencapai hasil yang diinginkan. Terkait dengan ini Gagne dalam Suherman (2003) mengungkapkan bahwa dalam bermatematika ada dua objek yang dapat diperoleh siswa yaitu objek langsung dan tak langsung. Objek tak langsung antara lain kemampuan menyelidiki dan memecahkan masalah, belajar mandiri, bersikap positif terhadap matematika dan tahu bagaimana semestinya belajar. Sedangkan objek langsung berupa fakta, keterampilan, konsep dan aturan. Kutipan ini menjelaskan bahwa dalam pembelajaran matematika siswa akan nenemukan berbagai fakta, konsep, aturan tertentu dan keterampilan untuk menyelidiki, memecahkan masalah, belajar mandiri dan belajar dengan teman. Sehingga siswa termotivasi dan bersemangat dalam belajar matematika.

Apabila kita ingin mengajarkan matematika kepada siswa dengan baik dan berhasil pertam-tama yang harus diperhatikan adalah metode atau cara yang akan dilakukan, sehingga sasaran yang diharapkan dapat tercapai atau terlaksana dengan baik, karena metode atau cara pendekatan yang dalam fungsinya merupakan alat untuk mencapai tujuan. Dengan demikian jika pengetahuan tentang metode dapat mengklasifikasikan dengan tepat maka sasaran untuk mencapai tujuan akan semakin efektif dan efisien. Strategi mengajar yang diterapkan dalam suatu pengajaran dikatakan efektif bila menghasilkan sesuatu sesuai dengan yang diharapkan atau dapat dikatakan tujuan telah tercapai. Sedangkan strategi mengajar dikatakan efisien jika penerapannya dalam menghasilkan sesuatu yang diharapkan itu relatif menggunakan tenaga, usaha pengeluaran biaya, dan waktu minimum, semakin kecil tenaga, usaha, biaya, dan waktu yang dikeluarkan maka semakin efisien strategi tersebut.

Pembelajaran Matematika yang Kreatif dan Menyenangkan :

Sebagaimana ungkapan sebelumnya bahwa tujuan pembelajaran matematika adalah membentuk kemampuan bernalar pada diri siswa yang tercermin melalui kemampuan berpikir kritis, logis, sistimatis dan memiliki sifat obyektif, jujur, disiplin dalam memecahkan suatu permasalahan baik dalam bidang matematika, bidang lain, maupun dalam kehidupan sehari-hari. Agar tujuan di atas tercapai maka guru sebagai komponen utama dalam pembelajaran harus berusaha untuk mencipkatan pembelajaran matematika yang kreatif dan menyenangkan.

Terkait dengan hal ini menurut Uno (2012) pemilihan strategi pembelajaran pada dasarnya merupakan salah satu hal penting yang harus dipahami oleh setiap guru, menginggat proses pembelajaran merupakan proses komunikasi ilmiah antar siswa, guru dan lingkungan belajar. Strategi pembelajaran yang dipilih oleh guru selayaknya didasari pada berbagai petrimbangan sesuai dengan situasi, 
kondisi, dan lingkungan yang akan dihadapi.

Selanjutnya menurut Uno pemilihan strategi pembelajaran bertolak dari 1) rumusan tujuan pembelajaran yang telah ditetapkan, 2) analisis kebutuhan dan karakter peserta didik yang dihasilkan, dan 3) jenis materi pelajaran yang akan dikomunikasikan. Ketiga elemen di atas disesuaikan dengan media pembelajaran atau sumber belajar yang tersedia dan mungkin digunakan. Dari uraian di atas jelaslah bahwa dalam pelaksanaan proses pembelajaran guru harus kreatif baik dalam memilih strategi maupun dalam menciptakan suasana belajar. Karena tugas utama seorang guru adalah untuk memudahkan pembelajaran siswa. Untuk memenuhi tugas ini guru harus dapat menyediakan suasana pembelajaran yang menarik dan harmonis, serta menciptakan pembelajaran yang berkesan. Artinya guru perlu mewujudkan suasana pembelajaran yang dapat merangsang minat siswa dan senantiasa memikirkan kebaikan dan keperluan siswa.

Seperti telah dikemukakan sebelumnya bahwa salah satu strategi pembelajaran yang dapat diterapkan dalam pembelajaran matematika adalah strategi pembelajaran PAILKEM (Pembelajaran Aktif, Inovatif, Lingkungan, Kreatif, Efektif, dan Menarik). Sinonim dari PAILKEM menurut Uno (2012) adalah sebagai berikut:

1) Pembelajaran yang Aktif

Konsep pembelajaran aktif bukanlah tujuan dari kegiatan pembelajaran, tetapi merupakan salah satu strategi yang digunakan untuk mengoptimalkan proses pembelajaran. Aktif dalam strategi ini adalah memposisikan guru sebagai orang yang menciptakan suasana belajar yang kondusif atau sebagai fasilitator dalam belajar, sementara siswa sebagai peserta belajar yang harus aktif. Dengan strategi pembelajaran yang aktif ini diharapkan akan tumbuh dan berkembang segala potensi yang dimiliki siswa sehingga pada akhirnya dapat mengoptimalkan hasil belajar. Untuk menciptakan pembelajaran yang aktif, guru dapat menerapkan berbagai metode pembelajaran serta model pembelajaran yang relevan, seperti: Model make a Match (mencari pasangan), Model Talking Stick, Model Snowbal Throwing, Model Bertukar pasangan dan lain-lain.

2) Pembelajaran yang Inovatif

Pembelajaran inovatif adalah suatu proses pembelajaran yang dirancang, disusun dan dikondisikan agar siswa aktif belajar. Tujuannya adalah agar dalam kegiatan pembelajaran terjadi hal-hal yang baru, bukan saja oleh guru sebagai fasilitator belajar, tetapi juga oleh siswa yang sedang belajar. Dalam pembelajaran yang inovatif guru tidak hanya bergantung pada buku, tetapi dapat mengimplementasikan hal-hal baru yang menurut guru sangat cocok dan relevan dengan masalah yang sedang dipelajari siswa. Begitu juga dengan siswa melalui aktivitas belajar siswa dapat menemukan caranya sendiri untuk menperdalam hal-hal yang sedang dipelajari. Untuk mencapai tujuan dan apa yang harus dikuasai siswa ada beberapa model pembelajaran inovatif dan pendekatannya diantaranya adalah: model pembelajaran kooperatif tipe STAD, Model Pembelajaran Group Investigation (GI), Model Pembelajaran berdasarkan masalah dan lain-lain.

3) Pembelajaran yang Menggunakan Lingkungan 
Strategi pembelajaran yang menggunakan liungkungan adalah salah satu strategi yang mendorong siswa agar belajar tidak tergantung dari apa yang ada dalam buku yang merupakan peganggan guru. Kosep pembelajaran ini berangkat dari belajar kontekstual dengan lebih mengedepankan bahwa hal yang perlu dipelajari terlebih dahulu oleh siswa adalah apa yang ada dilingkungannya.

4) Pembelajaran yang Kreatif Pembelajaran yang kreatif mendorong siswa untuk lebih bebas mempelajari makna yang ia pelajari. Karena pembelajaran yang kreatif bertujuan untuk mengembangkan kemapuan berfikir siswa. Untuk itu guru harus menciptakan kegiatan belajar yang beragam sehingga memenuhi berbagai tingkat kemampuan siswa. Jadi agar siswa dapat mengembangkan kreativitasnya maka guru harus lebih kreatif.

5) Pembelajaran yang Efektif

Pembelajaran efektif menghendaki agar siswa yang belajar telah membawa sejumlah potensi, lalu dikembangkan melalui kompetensi yang telah di tetapkan, dan dalam waktu tertentu kompetensi belajar dapat dicapai siswa dengan baik atau tuntas. Jadi pembelajaran dianggap efektif apabila skor yang dicapai siswa memenuhi batas minimal kompetensi yang telah dirumuskan setelah melalui proses pembelajaran dalam limit waktu tertentu. Agar pembelajaran yang efektif ini tercapai maka dalam menetapkan tujuan yang akan disusun dalam kompetensi dasar, indikator, dan tujuan pembelajaran perlu mempertimbangkan karateristik siswa. Untuk itu sebelum pembelajaran dilaksanakan dilakukan analisis karakteristik siswa berupa analis minat, bakat, kemampuan awal, atau motivasi belajar siswa hingga gaya belajarnya. Dengan kata lain pembelajaran yang efektif adalah pembelajaran yang mempertimbangkan karakteristik siswa, bagaimana kemampuannya, metode apa yang cocok digunakan, media apa yang pas diterapkan serta evaluasi belajarpun didasarkan pada kemampuan siswa.

6) Pembelajaran yang Menarik.

Pembelajaran yang menarik adalah konsep belajar yang membantu guru mengaitkan antara materi yang diajarkan dengan situasi dunia nyata siswa dan mendorong siswa membuat hubungan antara pengetahuan yang dimilikinya dengan menerapkannya dalam kehidupan mereka sehari-hari. Jadi pembelajaran yang menarik merupakan suatu proses pendidikan yang holistik dan bertujuan memotivasi siswa untuk memahami makna materi pelajaran yang dipelajarinya dengan mengaitkan materi tersebut dalam konteks atau permasalahan kehidupan mereka sehari-hari (konteks pribadi, sosial, dan kultural) sehingga siswa memiliki pengetahuan atau keterampilan yang secara fleksibel dapat diterapkan dari satu permasalahan ke permasalahan lainnya. Beberapa hal yang perlu diperhatikan dalam menciptakan pembelajaran yang menarik antara lain:

i) dalam menerapkan model pembelajaran harus sesuai dengan kondisi di mana tempat siswa itu berada,

ii) melakukan evaluasi lebih konprehensif yang tidak hanya mengukur kemampuan penguasaan bahan pembelajaran, tetapi juga kemampuan berfikir,

iii) menciptakan model pembelajaran yang lebih variatif dan merangsang 
kemampuan berfikir siswa yang tidak hanya bersifat informatifdeskriptif.

Berdasarkan uraian di atas jelaslah bahwa proses pembelajaran yang kreatif dan menyenangkan dapat diwujudkan melalui strategi PAILKEM, karena dalam proses pembelajaran PAILKEM terjadi dialog yang interaktif antara siswa dan siswa, siswa dan guru atau siswa dan sumber belajar lainnya. Suasana belajar demikian membuat siswa dapat saling bertanya dan berdiskusi sehingga siswa tidak terbebani secara perseorangan dalam memecahkan masalah yang dihadapi dalam belajar. Dengan strategi pembelajaran yang aktif ini, diharapkan akan tumbuh dan berkembang segala potensi yang dimiliki siswa dan pada akhirnya dapat mengoptimalkan hasil belajar.

\section{KESIMPULAN DAN SARAN}

Strategi mengajar yang diterapkan dalam suatu pengajaran dikatakan efektif bila menghasilkan sesuatu sesuai dengan yang diharapkan atau dapat dikatakan tujuan telah tercapai. Sedangkan strategi mengajar dikatakan efisien jika penerapannya dalam menghasilkan sesuatu yang diharapkan itu relatif menggunakan tenaga, usaha pengeluaran biaya, dan waktu minimum, semakin kecil tenaga, usaha, biaya, dan waktu yang dikeluarkan maka semakin efisien strategi tersebut.

Pemilihan strategi pembelajaran bertolak dari 1) rumusan tujuan pembelajaran yang telah ditetapkan, 2) analisis kebutuhan dan karakter peserta didik yang dihasilkan, dan 3) jenis materi pelajaran yang akan dikomunikasikan. Ketiga elemen di atas disesuaikan dengan media pembelajaran atau sumber belajar yang tersedia dan mungkin digunakan.

Strategi Pembelajaran PAILKEM (Pembelajaran Aktif, Inovatif, Lingkungan, Kreatif, Efektif, dan Menarik) merupakan salah satu strategi yang dapat diterapkan dalam kegiatan pembelajaran matematika. Karena strategi ini tertuju pada bagaimana cara 1) mengorganisasikan materi pembelajaran, 2) menyampaikan atau menggunakan metode pembelajaran, dan 3) mengelola pembelajaran sebagaimana yang dikehendaki oleh ilmuan pembelajaran saat ini.

Strategi PAILKEM dapat digunakan untuk mengoptimalkan proses pembelajaran. Strategi PAILKEM memposisikan guru sebagai orang yang menciptakan suasana belajar yang kondusif atau sebagai fasilitator dalam belajar. Sementara siswa sebagai peserta belajar harus aktif, inovatif dan lingkungan dimanfaatkan sebagai sumber belajar yang kreatif, efektif, dan menarik.

\section{UCAPAN TERIMAKASIH}

Penelitian ini terselenggara atas bantuan dari DP2M Dikti dan kerjasama dengan stakeholders yang telah memberikan tempat pelaksanaan penelitian.

\section{DAFTARPUSTAKA}

Common, Tex Book. (2001). Strategi Pembelajaran Matematika Kontemporer. Jakarta: JICA

Muslich, Masnur. (2007) Sertifikasi Guru Menuju Profesionalisme Pendidik. Jakarta: Bumi Aksara

\section{Ruseffendi, E.T. (1992). Pengantar kepada Membantu Guru Mengembangkan Kompetensinya dalam Pengajaran Matematika untuk Meningkatkan CBSA. Bandung : Tarsito}

Suherman, Erman dkk. (2003) Strategi Pembelajaran Matematika Kontemporer. Bandung: Universitas Pendidikan Indonesia 
Trianto. (2010) Mendesain Model Pembelajaran Inovatif-Progresif. Jakarta: Kencana Media Group 